\title{
THE EFFECT OF ORAL PROTEIN AND GLUCOSE FEEDING ON SPLANCHNIC BLOOD FLOW AND OXYGEN UTILIZATION IN NORMAL AND CIRRHOTIC SUBJECTS ${ }^{1,2}$
}

\author{
By J. LEONARD BRANDT, LEONARD CASTLEMAN, HERMAN D. RUSKIN, \\ JACK GREENWALD, AND JOHN J. KELLY, JR, WITH THE TECHNICAL \\ ASSISTANCE OF AUDREY JONES
}

\author{
(From The Department of Medicine, State University of New York, College of Medicine at \\ New York City and the Kings County Hospital Center, Brooklyn, N. Y.)
}

(Submitted for publication November 1, 1954; accepted March 16, 1955)

Since the dietary management of patients with cirrhosis is of great importance it was felt that assessment of the vascular and metabolic responses of the splanchnic area to protein and glucose feeding would shed some light on reactions of the splanchnic vasculature and of the liver parenchyma which might be therapeutically desirable, or the reverse.

\section{METHODS}

The subjects for this investigation were patients from the Medical Wards of the University Service, Kings County Hospital. A total of 40 patients were studied. Fourteen patients who had recovered from recent acute infections or other minor illnesses and were considered to have normal liver function by the usual clinical and laboratory criteria, served as a control group. There were 26 subjects in the cirrhotic group. Twenty-one of these cirrhotic patients had a history of prolonged excessive alcoholic intake and poor nutrition; 5 had a history of acute hepatitis years previous to the onset of their present illness. The diagnosis of cirrhosis was supported by laboratory studies in all cases, and in 15 subjects by liver biopsy. Ten of the cirrhotic patients had ascites and paracenteses were performed 24 hours before study so that they were as "dry" as possible during the study.

The estimated splanchnic blood flow (ESBF) and splanchnic oxygen consumption (SOC) were determined in all subjects in the morning after a fast of at least 12 hours, and for variable periods up to 90 minutes following the ingestion of either protein or glucose. The splanchnic blood flow was determined by the bromsulfalein (BSP) method (3). An infusion of BSP (in 0.85 per cent saline) was administered intravenously at a constant rate maintained in a few instances by a tunnel clamp and in the remaining cases by a calibrated Bowman pump. The rate of infusion was adjusted so

1 This work was supported by a grant from Abbott Laboratories, North Chicago, Illinois.

2 Portions of this work were presented at the Eastern Section Meeting, American Federation for Clinical Research, Boston, January 4, 1954 (1) and have appeared in abstract (2). that the peripheral BSP concentration was maintained at a constant level throughout each study below 2.0 mgm. per cent following a priming dose of $150 \mathrm{mgm}$. A specially designed double lumen venous catheter in which the lumina are 3 inches apart was introduced into the right hepatic vein under fluoroscopic control, advanced as far as possible, and was kept in that position throughout each study. All blood sampling was done from the proximal opening, which was positioned in a branch of the hepatic vein. Samples of blood for arterial oxygen content and BSP concentration were obtained through an indwelling arterial needle in either the femoral or brachial artery. Thirty to 60 minutes after the establishment of proper BSP levels 3 or 4 simultaneous samples of arterial and hepatic venous blood were obtained at 5 to 10 -minute intervals for colorimetric determination of plasma bromsulfalein concentration. Samples of arterial and hepatic venous blood were also obtained without exposure to air for the determination of oxygen differences. Care was taken to assure a free flow of blood from the catheter so as to prevent inadvertent dilution and thus invalid determinations.

The estimated splanchnic plasma flow was calculated from extrapolated data midway between two successive determinations of arterial and hepatic vein BSP plasma concentrations. The splanchnic oxygen consumption (SOC) was calculated only in those instances when arterial and hepatic vein oxygen samples were obtained within five minutes of this extrapolated midpoint.

In those instances where the peripheral BSP concentration was changing more than $0.003 \mathrm{mgm}$. per cent per minute $(\Delta \mathrm{P})$ the data were considered invalid and discarded. In those instances where the arterial minus hepatic vein (A-HV) BSP concentration divided by arterial BSP concentration, $E_{B 8 P}$ per cent, that is the hepatic extraction of bromsulfalein, was less than 10 per cent during control periods, blood flow was not estimated. In both normal and cirrhotic subjects fed protein the BSP concentration in the hepatic vein rose with no detectable change in peripheral BSP levels indicating a decrease in $E_{\text {BgP }}$ per cent. In a few instances there was a concomitant slight rise in peripheral BSP levels with the fall in $E_{\text {BsP }}$ per cent indicating a decrease in over-all BSP clearance. Estimated splanchnic blood flow was determined from values for estimated plasma flow and arterial hematocrits which were measured in Wintrobe 
tubes centrifuged at $3,000 \mathrm{rpm}$ for 30 minutes. It was assumed that the peripheral arterial and splanchnic hematocrits maintained a constant relationship to each other throughout each study. Data for both ESBF and SOC have been converted to rates per square meter of body surface. Per cent changes represent the increases or decreases from average control values. All data were discarded if the splanchnic blood flow in any one of three successive control periods varied more than 10 per cent from the mean ESBF of these periods. Recorded post feeding data are single determinations.

In the cirrhotic group fed protein there were seven subjects with hyperbilirubinemia in whom ESBF was not measured. Blood was drawn from the collateral abdominal veins of two cirrhotic patients for the determination of amino acid nitrogen content.

Following three control periods, the subjects in whom the effects of protein feeding were to be studied, ingested 250 grams of chopped lean beef which contained 60 grams of protein. The meat was broiled, homogenized in a Waring blendor with water and salt, and then reheated. The consistency of the meal was approximately that of a thick soup and could easily be taken through a glass straw by the patient while he remained in the supine position. In the glucose feeding studies the pa- tients ingested 100 grams of glucose to which lemon juice had been added. Protein and glucose feedings were of approximately equal volume $(500 \mathrm{cc}$.), but were not isocaloric.

After either of these two feedings the sampling of hepatic venous and arterial blood permitted determinations of bromsulfalein and oxygen, and in certain instances amino acid nitrogen and glucose content. Since carefully selected beef was used for protein feeding, alimentary lipemia did not interfere with the colorimetric determinations of BSP. Sampling was started as early as five minutes after the feeding in some instances, and as late as 30 minutes afterwards in others. Specimens were obtained at approximately 10 to 15-minute intervals up to 90 minutes after the ingestion of the food.

Arteriovenous oxygen differences were determined once during the control periods, again during the first 50 minutes after feeding, and at least once more before the study was terminated. The oxygen concentrations were determined by the manometric method of Van Slyke and Neill (4); glucose concentrations from zinc sulfate filtrates by a modification of the Somogyi method (5); amino acid nitrogen from tungstate filtrates by a modification of the Folin-Wu method (6).

TABLE I

The effect of oral protein feeding in normal subjects

\begin{tabular}{|c|c|c|c|c|c|c|c|c|c|c|}
\hline \multirow[b]{2}{*}{ Subject } & & \multirow{2}{*}{$\begin{array}{l}\text { Fasting } \\
\text { control }\end{array}$} & \multicolumn{8}{|c|}{ Time (minutes) after feeding } \\
\hline & & & 20 & 30 & 40 & 50 & 60 & 70 & 80 & 90 \\
\hline $\begin{array}{l}\text { N. K. } \\
\text { (M) }\end{array}$ & $\begin{array}{l}\text { ESBF } \\
\text { SOC } \\
\text { A-HV O, }\end{array}$ & $\begin{array}{r}1090 \\
37 \\
3.4\end{array}$ & & $\begin{array}{c}1575(45)^{*} \\
46(24) \\
2.9\end{array}$ & $1510(39)$ & $1370(26)$ & $\begin{array}{c}1190(9) \\
48(30) \\
4.0\end{array}$ & & & \\
\hline $\begin{array}{l}\text { V. G. } \\
\text { (M) }\end{array}$ & $\begin{array}{l}\text { ESBF } \\
\text { SOC } \\
\text { A-HV O, }\end{array}$ & $\begin{array}{r}920 \\
33 \\
3.6\end{array}$ & & & $\begin{array}{l}980(7) \\
42(28) \\
4.3\end{array}$ & $1240(35)$ & $1220(33)$ & $1215(32)$ & $\begin{array}{c}1160(26) \\
57(73) \\
4.9\end{array}$ & \\
\hline $\begin{array}{l}\text { J. B. } \\
\text { (M) }\end{array}$ & $\begin{array}{l}\text { ESBF } \\
\text { SOC } \\
\text { A-HV O, }\end{array}$ & $\begin{array}{r}1340 \\
59 \\
4.4\end{array}$ & & & & $\begin{array}{c}1780(33) \\
70(19) \\
3.9\end{array}$ & & $\begin{array}{c}1760(31) \\
92(56) \\
5.2\end{array}$ & $1755(31)$ & $\begin{array}{c}1485(11) \\
77(31) \\
5.2\end{array}$ \\
\hline $\begin{array}{l}\text { W. O'C. } \\
\text { (M) }\end{array}$ & $\begin{array}{l}\text { ESBF } \\
\mathrm{SOC} \\
\mathrm{A}-\mathrm{HV} \mathrm{O} \mathrm{O}_{2}\end{array}$ & $\begin{array}{r}1205 \\
45 \\
3.7\end{array}$ & & & $1430(19)$ & $\begin{array}{c}1365(13) \\
74(64) \\
5.4\end{array}$ & $1205(0)$ & $\begin{array}{c}1105(-8) \\
69(53) \\
6.2\end{array}$ & & \\
\hline $\begin{array}{l}\text { C. S. } \\
\text { (F) }\end{array}$ & $\begin{array}{l}\text { ESBF } \\
\text { SOC } \\
\text { A-HV O2 }\end{array}$ & $\begin{array}{r}970 \\
28 \\
2.9\end{array}$ & & & & $\begin{array}{c}1225(26) \\
45(61) \\
4.3\end{array}$ & & $\begin{array}{c}1190(23) \\
36(29) \\
3.0\end{array}$ & $1135(17)$ & $1070(10)$ \\
\hline $\begin{array}{l}\text { S. P. } \\
\text { (M) }\end{array}$ & $\begin{array}{l}\text { ESBF } \\
\text { SOC } \\
\text { A-HV O, }\end{array}$ & $\begin{array}{r}1130 \\
70 \\
6.1\end{array}$ & $1800(59)$ & $1760(56)$ & $\begin{array}{c}1670(48) \\
95(36) \\
5.7\end{array}$ & $1730(53)$ & & $1690(50)$ & $\begin{array}{l}1755(55) \\
109(56) \\
5.4\end{array}$ & $1705(51)$ \\
\hline $\begin{array}{l}\text { A. W. } \\
\text { (M) }\end{array}$ & $\begin{array}{l}\text { ESBF } \\
\text { SOC } \\
\text { A-HV O, }\end{array}$ & $\begin{array}{r}1480 \\
49 \\
3.3\end{array}$ & & $\begin{array}{c}2000(35) \\
82(67) \\
4.1\end{array}$ & & $2130(44)$ & $2080(41)$ & & $\begin{array}{c}1820(23) \\
64(31) \\
3.5\end{array}$ & \\
\hline $\begin{array}{l}\text { Average } \\
\text { of } \\
\text { control }\end{array}$ & $\begin{array}{l}\text { ESBF } \\
\text { SOC } \\
\text { A-HV O, }\end{array}$ & $\begin{array}{r}1160 \\
46 \\
3.9\end{array}$ & $\begin{array}{l}\text { Averaget } \\
\text { through } 5 \\
\text { period }\end{array}$ & $\begin{array}{l}\text { of } 20 \\
0 \text {-minute }\end{array}$ & $\begin{array}{c}1570(35) \\
65(41) \\
4.4\end{array}$ & & $\begin{array}{l}\text { Averaget } \\
\text { through } 9 \\
\text { period }\end{array}$ & 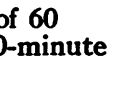 & $\begin{array}{c}1430(23) \\
69(50) \\
4.7\end{array}$ & \\
\hline
\end{tabular}

* Data in parentheses represent percentage increases or decreases (-) from control.

† The average ESBF recorded was derived from average data of each individual during the two main time periods; e.g., the ESBF for subject N. K. during 10 through 50 -minute period was 1485 , and 1190 during 60 through 90 -minute period. 
TABLE II

The effect of oral protein feeding in cirrhotic subjects

\begin{tabular}{|c|c|c|c|c|c|c|c|c|c|c|c|}
\hline \multirow[b]{3}{*}{ Subject } & \multicolumn{11}{|c|}{ A. Non-icteric } \\
\hline & & \multirow{2}{*}{$\begin{array}{l}\text { Fasting } \\
\text { control }\end{array}$} & \multicolumn{9}{|c|}{ Time (minutes) after feeding } \\
\hline & & & 10 & 20 & 30 & 40 & 50 & 60 & 70 & 80 & 90 \\
\hline $\begin{array}{l}\text { J. W. } \\
\text { (M) }\end{array}$ & $\begin{array}{l}\text { ESBF } \\
\text { SOC } \\
\text { A-HVO, }\end{array}$ & $\begin{array}{r}380 \\
21 \\
2 \quad 5.4\end{array}$ & & & & $\begin{array}{l}445(17) \\
21(0) \\
4.7\end{array}$ & $495(30)$ & $405(7)$ & $360(-5)$ & & $\begin{array}{c}435(12) \\
30(43) \\
7.0\end{array}$ \\
\hline $\begin{array}{l}\text { J. T. } \\
\text { (M) }\end{array}$ & $\begin{array}{l}\text { ESBF } \\
\text { SOC } \\
\text { A-HVO }\end{array}$ & $\begin{array}{r}1075 \\
36 \\
2 \quad 3.3\end{array}$ & & & & & $\begin{array}{c}1390(29) \\
54(50) \\
3.9\end{array}$ & $1160(8)$ & $\begin{array}{c}940(-13) \\
30(-17) \\
3.2\end{array}$ & & \\
\hline $\begin{array}{l}\text { A. McC. } \\
\text { (M) }\end{array}$ & $\begin{array}{l}\text { ESBF } \\
\text { SOC } \\
\text { A-HVO, }\end{array}$ & $\begin{array}{r}725 \\
51 \\
2 \quad 7.1\end{array}$ & & & & $\begin{array}{c}840(16) \\
40(-22) \\
4.8\end{array}$ & $910(26)$ & $\begin{array}{l}980(35) \\
63(24) \\
6.4\end{array}$ & & & \\
\hline $\begin{array}{l}\text { C. M. } \\
\text { (M) }\end{array}$ & $\begin{array}{l}\text { ESBF } \\
\text { SOC } \\
\text { A-HVO, }\end{array}$ & $\begin{array}{r}1025 \\
70 \\
2 \quad 6.9\end{array}$ & $1065(4)$ & & $\begin{array}{c}1130(10) \\
67(-4) \\
5.9\end{array}$ & & & $1090(6)$ & $\begin{array}{c}1130(10) \\
70(0) \\
6.2\end{array}$ & & $\begin{array}{c}1220(19) \\
89(27) \\
7.3\end{array}$ \\
\hline $\begin{array}{l}\text { W. R. } \\
\text { (M) }\end{array}$ & $\begin{array}{l}\text { ESBF } \\
\text { SOC } \\
\text { A-HVO } \\
\end{array}$ & $\begin{array}{r}780 \\
42 \\
2 \quad 5.2 \\
\end{array}$ & & $\begin{array}{c}840(8) \\
48(14) \\
5.7\end{array}$ & $950(22)$ & & $935(20)$ & & $\begin{array}{c}945(21) \\
53(26) \\
5.6\end{array}$ & & $800(3)$ \\
\hline $\begin{array}{l}\text { T. D. } \\
\text { (M) }\end{array}$ & $\begin{array}{l}\text { ESBF } \\
\text { SOC } \\
\text { A-HVO, }\end{array}$ & $\begin{array}{r}570 \\
16 \\
2 \quad 2.8\end{array}$ & & $\cdot$ & $985(73)$ & $\begin{array}{c}865(52) \\
37(131) \\
4.3\end{array}$ & $750(32)$ & $785(38)$ & & $930(63)$ & $\begin{array}{c}930(63) \\
28(75) \\
3.0\end{array}$ \\
\hline $\begin{array}{l}\text { J. R. } \\
\text { (M) }\end{array}$ & $\begin{array}{l}\text { ESBF } \\
\text { SOC } \\
\text { A-HVO, }\end{array}$ & $\begin{array}{r}1400 \\
45 \\
2 \quad 3.2\end{array}$ & & $1510(8)$ & $\begin{array}{c}1710(22) \\
55(22) \\
3.2\end{array}$ & $1305(-7)$ & & $\begin{array}{c}1275(-9) \\
42(-7) \\
3.3\end{array}$ & & & \\
\hline $\begin{array}{l}\text { P.A. } \\
\text { (M) }\end{array}$ & $\begin{array}{l}\text { ESBF } \\
\text { SOC } \\
\text { A-HVO, }\end{array}$ & $\begin{array}{r}410 \\
24 \\
\quad 5.8\end{array}$ & $415(1)$ & & $\begin{array}{l}445(8) \\
29(21) \\
6.2\end{array}$ & & & & & & \\
\hline $\begin{array}{l}\text { E. A. } \\
\text { (M) }\end{array}$ & $\begin{array}{l}\text { ESBF } \\
\text { SOC } \\
\text { A-HVO, }\end{array}$ & $\begin{array}{r}905 \\
44 \\
2 \quad 4.9\end{array}$ & & & $\begin{array}{c}1450(60) \\
64(45) \\
4.5\end{array}$ & & & $\begin{array}{c}1260(39) \\
52(14) \\
4.1\end{array}$ & & & \\
\hline$\underset{(\mathbf{M})}{\mathrm{N} . \mathrm{J}}$ & A-HVO, & 6.6 & 6.3 & & & & & & & & 6.2 \\
\hline $\begin{array}{l}\text { E. I. } \\
\text { (M) }\end{array}$ & A-HVO, & 6.2 & & & 6.8 & & & & 6.1 & & \\
\hline $\begin{array}{l}\text { I. T. } \\
\text { (M) }\end{array}$ & A-HVO, & 3.8 & & 5.5 & & & & 4.6 & & & \\
\hline $\begin{array}{l}\text { L.S. } \\
\text { (M) }\end{array}$ & A-HVO, & 2.6 & & & 3.3 & & & & & & \\
\hline $\begin{array}{l}\text { Average } \\
\text { of } \\
\text { control }\end{array}$ & $\begin{array}{l}\text { ESBF } \\
\text { SOC } \\
\text { A-HVO, }\end{array}$ & $\begin{array}{r}810 \\
39 \\
2 \quad 4.9\end{array}$ & $\begin{array}{l}\text { Averag } \\
10 \text { thro } \\
\text { minute }\end{array}$ & $\begin{array}{l}\text { lge of } \\
\text { rough } 50 \text { - } \\
\text { te period }\end{array}$ & & $\begin{array}{c}1000(23) \\
46(18) \\
5.0\end{array}$ & & $\begin{array}{l}\text { Average } \\
60 \text { throu } \\
\text { minute } 1\end{array}$ & $\begin{array}{l}\text { eof } \\
\text { ugh } 90- \\
\text { period }\end{array}$ & & $\begin{array}{l}985(21) \\
51(31) \\
5.3\end{array}$ \\
\hline
\end{tabular}

RESULTS

Since all control data represent similar fasting conditions for both types of experiment (protein and glucose feeding) the results are calculated as grouped data in normal and cirrhotic subjects. In each table, however, recorded averages were derived from data in the particular table.

\section{Control periods}

The mean control ESBF for 10 normal subjects (Table I, 7 subjects and Table IIIA, the first 3 subjects) was $1130 \mathrm{cc}$. per min. per $\mathrm{m}^{2} \pm 340 \mathrm{cc}$. The mean SOC for these 10 normal subjects was $43.5 \mathrm{cc}$. per min. per $\mathrm{m}^{2} \pm 7.5 \mathrm{cc}$. The mean A-HV oxygen difference for 14 normal subjects 
TABLE I-Continued

\begin{tabular}{|c|c|c|c|c|c|c|c|c|c|c|c|}
\hline \multicolumn{12}{|c|}{ B. Icteric } \\
\hline \multirow[b]{2}{*}{ Subject } & \multirow{2}{*}{\multicolumn{2}{|c|}{$\begin{array}{l}\text { Fasting } \\
\text { control }\end{array}$}} & \multicolumn{9}{|c|}{ Time (minutes) after feeding } \\
\hline & & & 10 & 20 & 30 & 40 & 50 & 60 & 70 & 80 & 90 \\
\hline $\begin{array}{l}\text { W. L. } \\
\text { (M) }\end{array}$ & A-HVO & 3.3 & & & & 3.1 & & & 3.7 & & \\
\hline J.V. & $\mathrm{A}-\mathrm{HVO}_{2}$ & 3.3 & & & & 4.5 & & & 5.3 & & \\
\hline $\begin{array}{l}\text { D. D. } \\
(\mathrm{M})\end{array}$ & $\mathrm{A}-\mathrm{HVO}_{2}$ & 1.5 & & & & 1.2 & & & & & 2.2 \\
\hline $\begin{array}{l}\mathbf{W . B} . \\
(\mathbf{M})\end{array}$ & A-HVO & 2.3 & & & . & & & & & 4.3 & \\
\hline $\begin{array}{l}\text { A.A. } \\
(\mathbf{M})\end{array}$ & A-HVO, & 1.9 & & & 4.0 & & & 4.0 & & & \\
\hline $\begin{array}{l}\text { P. H. } \\
(\mathbf{M})\end{array}$ & $\mathrm{A}-\mathrm{HVO}_{2}$ & 2.4 & & 2.8 & & & & 2.8 & & & \\
\hline $\begin{array}{l}\text { H.J. } \\
(\mathbf{M})\end{array}$ & $\mathrm{A}-\mathrm{HVO}_{2}$ & 2.8 & & & 3.7 & & & & & & \\
\hline Average & A-HVO, & $=2.5$ & $\begin{array}{l}\text { Ave } \\
10 \mathrm{t} \\
\mathrm{min}\end{array}$ & $\begin{array}{l}\text { e of } \\
\text { ugh } 50- \\
\text { period }\end{array}$ & $=3.2$ & & & & $\begin{array}{l}\text { Avera } \\
60 \text { th } \\
\text { minut }\end{array}$ & iod & $=3.5$ \\
\hline
\end{tabular}

(10 subjects cited above plus the last 4 subjects, Table IIIA) was 4.0 vol. per cent $\pm 0.8 \mathrm{cc}$.

The mean control ESBF for 11 non-icteric cirrhotic subjects (Table IIA, the first 9 subjects and Table IIIB, the first 2 subjects) was $730 \mathrm{cc}$. per min. per $\mathrm{m}^{2} \pm 340 \mathrm{cc}$. The mean SOC for these 11 subjects was $40.5 \mathrm{cc}$. per min. per $\mathrm{m}^{2} \pm 16 \mathrm{cc}$. The mean A-HV oxygen difference for 19 nonicteric cirrhotic subjects (11 subjects cited above plus the last 4 subjects, Table IIA and the last 4 subjects, Table IIIB) was 4.8 vol. per cent \pm 1.4 cc. In the 7 cirrhotic subjects with clinical icterus (Table IIB), the mean A-HV oxygen difference was 2.5 vol. per cent $\pm 0.7 \mathrm{cc}$.

\section{Post feeding results}

A. Protein. Tables I, IIA, and IIB list the effects of protein feeding in normal and cirrhotic subjects.

In the group of seven normal subjects (Table I) the average ESBF increased from a fasting value of $1160 \mathrm{cc}$. per min. per $\mathrm{m}^{2}$ to $1570 \mathrm{cc}$. per min. per $\mathrm{m}^{2}, 35$ per cent above the control in the first hour after the protein feed. During the next thirty minutes there was some return towards control levels, the ESBF averaging $1430 \mathrm{cc}$. per min. per $\mathrm{m}^{2}, 23$ per cent above control. There was also an increase in the average $\mathrm{A}-\mathrm{HV}$ oxygen difference for the normal subjects from a control value of 3.9 vol. per cent to 4.4 vol. per cent during the first hour after feeding and a further increase to 4.7 vol. per cent in the next 30 minutes. The average fasting SOC of $46 \mathrm{cc}$. per min. per $\mathrm{m}^{2}$ rose to 65 cc. per min. per $\mathrm{m}^{2}$, a 41 per cent increase, during the first post feeding hour and reached $69 \mathrm{cc}$. per min. per $\mathrm{m}^{2}$, to a 50 per cent increase during the next thirty minutes. Although there was a slight decrease in the average ESBF during the last thirty minutes of observation, as compared with the ESBF of the first hour, the increased A-HV oxygen difference at the time was greater so that the SOC increased.

In 9 non-icteric cirrhotic subjects (Table IIA) the ESBF rose from an average level of $810 \mathrm{cc}$. per min. per $\mathrm{m}^{2}$ in the fasting state to $1000 \mathrm{cc}$. per min. per $\mathrm{m}^{2}, 23$ per cent above control, during the first hour post feeding, and fell slightly to $985 \mathrm{cc}$. per min. per $\mathrm{m}^{2}$, still 21 per cent above control during the final 30 minutes of observation. A-HV oxygen differences in the 13 non-icteric cirrhotic subjects (Table IIA) changed insignificantly after feeding from an average fasting level of $4.9 \mathrm{vol}$. per cent to 5.0 vol. per cent during the first hour and to 5.3 vol. per cent in the next 30 minutes. From an average fasting SOC of $39 \mathrm{cc}$. per min. per $\mathrm{m}^{2}$ there was an increase to $46 \mathrm{cc}$. per min. per 
TABLE III

The effect of oral glucose feedings

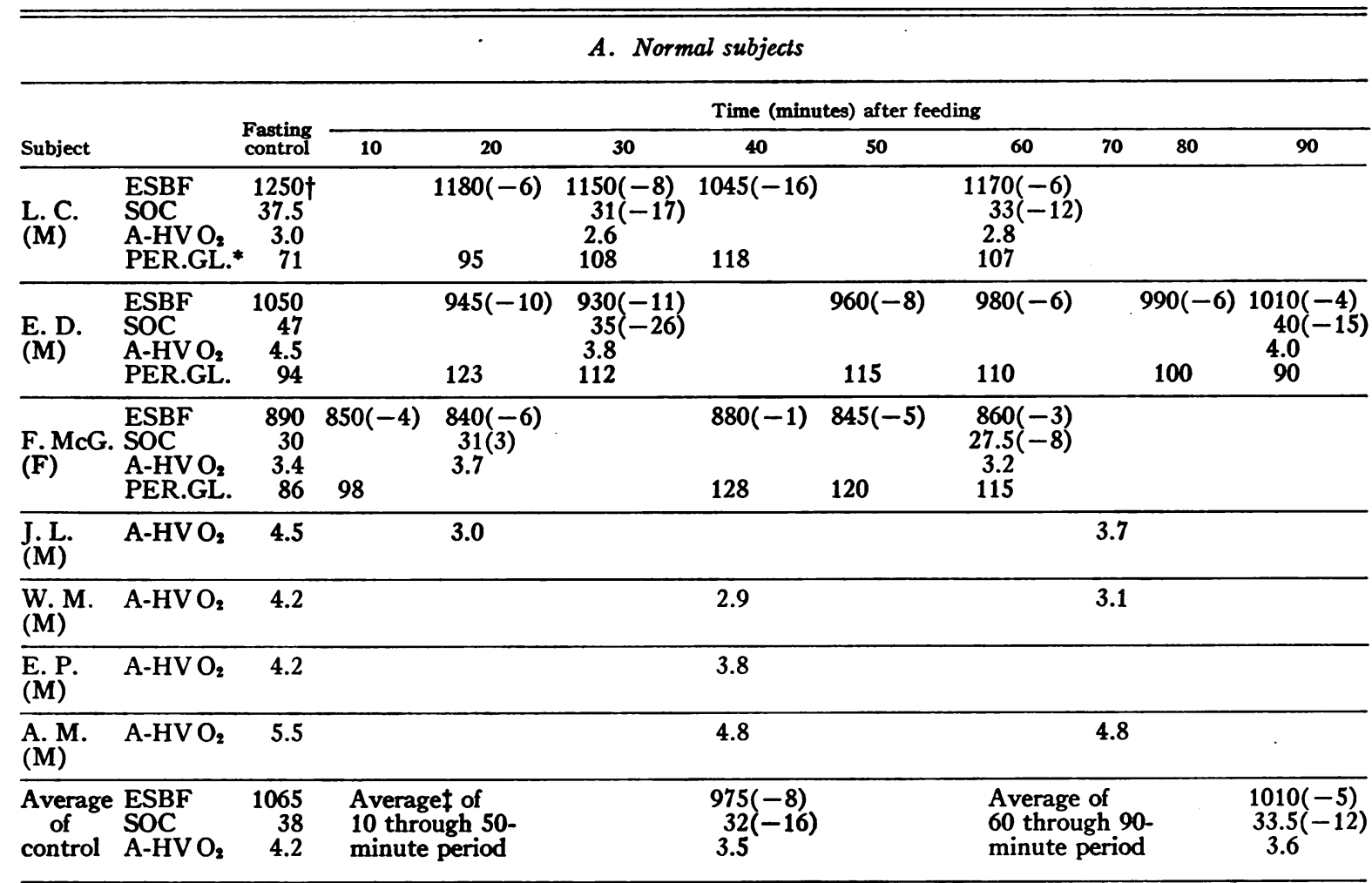

B. Cirrhotics

\begin{tabular}{|c|c|c|c|c|c|c|c|c|c|c|c|}
\hline \multirow[b]{2}{*}{ Subject } & & \multirow{2}{*}{$\begin{array}{l}\text { Fasting } \\
\text { control }\end{array}$} & \multicolumn{9}{|c|}{ Time (minutes) after feeding } \\
\hline & & & 10 & 20 & 30 & 40 & 50 & 60 & 70 & 80 & 90 \\
\hline$\underset{(\mathbf{M})}{\text { N.P. }}$ & $\begin{array}{l}\text { ESBF } \\
\text { SOC } \\
\text { A-HVO } \\
\text { PER.GL. }\end{array}$ & $\begin{array}{r}590 \\
38 \\
6.5 \\
80\end{array}$ & & & $\begin{array}{c}540(-8) \\
32(-16) \\
5.9 \\
124\end{array}$ & & $\begin{array}{l}590(0) \\
120\end{array}$ & & & & \\
\hline $\begin{array}{l}\text { P. M. } \\
\text { (M) }\end{array}$ & $\begin{array}{l}\text { ESBF } \\
\text { SOC } \\
\text { A-HV O } \\
\text { PER.GL. }\end{array}$ & $\begin{array}{r}1175 \\
59 \\
5.0 \\
74\end{array}$ & & $\begin{array}{l}700(-40) \\
24.5(-58) \\
3.5 \\
112\end{array}$ & $825(-30)$ & & & $\begin{array}{c}930(- \\
48(- \\
5.2 \\
80\end{array}$ & & & \\
\hline $\begin{array}{l}\text { N. L. } \\
\text { (M) }\end{array}$ & A-HVO, & 4.0 & & & & 4.4 & & 3.4 & & & \\
\hline $\begin{array}{l}\text { A. K. } \\
(\mathrm{M})\end{array}$ & A-HVO, & 3.6 & & & 3.7 & & & 2.8 & & & \\
\hline $\begin{array}{l}\text { S. K. } \\
(\mathrm{M})\end{array}$ & $\mathrm{A}-\mathrm{HVO}_{2}$ & 4.0 & & & 2.9 & & & 2.9 & & & \\
\hline $\begin{array}{l}\text { C. G. } \\
(\mathbf{M})\end{array}$ & $\mathrm{A}-\mathrm{HVO}_{2}$ & 4.3 & & 3.7 & & & & & 2. & 9 & \\
\hline $\begin{array}{l}\begin{array}{l}\text { Average } \\
\text { of } \\
\text { control }\end{array}\end{array}$ & $\begin{array}{l}\text { ESBF } \\
\text { SOC } \\
\text { A-HV O }\end{array}$ & $\begin{array}{r}880 \\
48 \\
4.6\end{array}$ & $\begin{array}{l}\text { Ave } \\
10 \mathrm{t} \\
\mathrm{min}\end{array}$ & $\begin{array}{l}\text { ze of } \\
\text { ough 50- } \\
\text { e period }\end{array}$ & & $\overline{\overline{4}}$ & & $\begin{array}{l}\text { Aver } \\
60 \text { th } \\
\text { minu }\end{array}$ & $\begin{array}{l}\text { of } \\
\text { igh } 90 \text { - } \\
\text { period }\end{array}$ & & $\bar{z}$ \\
\hline
\end{tabular}

* Peripheral (arterial) blood glucose level, mgm. per cent.

t Recorded control ESBF in each subject is the average of three successive determinations.

\pm Recorded average ESBF in the 10 through 50 -minute and in the 60 through 90 -minute periods was obtained by using the average ESBF of each subject during these two intervals, e.g., the ESBF in patient L. C. in the 10 through 50-minute period averaged $1125 \mathrm{cc}$. 
$\mathrm{m}^{2}$ or 18 per cent above control during the first hour after the meal, and then a very slight further increase to $51 \mathrm{cc}$. or 31 per cent above the control during the last 30 minutes of observation.

In the seven icteric cirrhotic subjects (Table IIB) there was a progressive increase in A-HV oxygen difference from a low average fasting level of $2.5 \mathrm{vol}$. per cent to $3.2 \mathrm{vol}$. per cent during the first hour post feeding, and to 3.5 vol. per cent during the next 30 minutes of observation.

In subjects I. T. and L. S. (Table IIA) with large abdominal collateral veins, amino acid nitrogen concentration rose in these vessels from fasting levels of 7.0 and $5.8 \mathrm{mgm}$. per cent to 15.4 and $14.8 \mathrm{mgm}$. per cent, respectively, twenty minutes after a protein feed. At one hour the levels were 16.0 and $17.0 \mathrm{mgm}$. per cent, respectively.

TABLE IV

Blood amino acid nitrogen levels in peripheral artery and hepatic vein before and one hour after protein feeding

\begin{tabular}{|c|c|c|c|}
\hline \multicolumn{4}{|c|}{ A. Cirrhotics } \\
\hline Subject & Time & Periph. Art. & Hep. Vein \\
\hline P. A. & $\begin{array}{l}\text { Cont. } \\
1 \text { hour }\end{array}$ & $\begin{array}{l}6.0 \\
8.0\end{array}$ & $\begin{array}{l}4.8 \\
7.4\end{array}$ \\
\hline E. A. & $\begin{array}{l}\text { Cont. } \\
1 \text { hour }\end{array}$ & $\begin{array}{r}6.3 \\
12.1\end{array}$ & $\begin{array}{r}9.5 \\
12.9\end{array}$ \\
\hline N. J. & $\begin{array}{l}\text { Cont. } \\
1 \text { hour }\end{array}$ & $\begin{array}{r}6.9 \\
10.7\end{array}$ & $\begin{array}{r}7.0 \\
12.0\end{array}$ \\
\hline P. H. & $\begin{array}{l}\text { Cont. } \\
1 \text { hour }\end{array}$ & $\begin{array}{l}7.7 \\
9.8\end{array}$ & $\begin{array}{l}6.1 \\
9.1\end{array}$ \\
\hline W. L. & $\begin{array}{l}\text { Cont. } \\
1 \text { hour }\end{array}$ & $\begin{array}{l}5.8 \\
9.9\end{array}$ & $\begin{array}{r}5.2 \\
12.4\end{array}$ \\
\hline A. A. & $\begin{array}{l}\text { Cont. } \\
1 \text { hour }\end{array}$ & $\begin{array}{r}6.6 \\
11.1\end{array}$ & $\begin{array}{r}6.0 \\
10.9\end{array}$ \\
\hline J. R. & $\begin{array}{l}\text { Cont. } \\
1 \text { hour }\end{array}$ & $\begin{array}{l}5.6 \\
6.5\end{array}$ & $\begin{array}{l}5.6 \\
5.9\end{array}$ \\
\hline E. I. & $\begin{array}{l}\text { Cont. } \\
1 \text { hour }\end{array}$ & $\begin{array}{r}6.9 \\
12.4 \\
\end{array}$ & $\begin{array}{l}5.9 \\
8.2 \\
\end{array}$ \\
\hline Average & $\begin{array}{l}\text { Cont. } \\
1 \text { hour }\end{array}$ & $\begin{array}{r}6.5 \\
10.1\end{array}$ & $\begin{array}{l}6.2 \\
8.6\end{array}$ \\
\hline \multicolumn{4}{|c|}{ B. Normals } \\
\hline A. W. & $\begin{array}{l}\text { Cont. } \\
1 \text { hour }\end{array}$ & $\begin{array}{l}6.3 \\
6.5\end{array}$ & $\begin{array}{l}6.1 \\
6.0\end{array}$ \\
\hline J. B. & $\begin{array}{l}\text { Cont. } \\
1 \text { hour }\end{array}$ & $\begin{array}{l}7.0 \\
7.2 \\
\end{array}$ & $\begin{array}{l}6.9 . \\
7.0 \\
\end{array}$ \\
\hline Average & $\begin{array}{l}\text { Cont. } \\
1 \text { hour }\end{array}$ & $\begin{array}{l}6.7 \\
6.8\end{array}$ & $\begin{array}{l}6.5 \\
6.5\end{array}$ \\
\hline
\end{tabular}

In eight cirrhotic subjects (Table IV) the peripheral amino acid nitrogen concentrations rose from an average fasting level of $6.5 \mathrm{mgm}$. per cent to $10.1 \mathrm{mgm}$. per cent one hour after protein ingestion while the corresponding hepatic vein concentrations increased from $6.2 \mathrm{mgm}$. per cent to $8.6 \mathrm{mgm}$. per cent in the same interval. In two of the eight subjects amino acid nitrogen levels in the hepatic vein were significantly higher than their corresponding peripheral levels one hour after the protein feed. In two normal subjects there was no significant change in amino acid nitrogen levels in either arterial or hepatic vein blood one hour after the feeding.

$B$. Glucose. In three normal subjects (Table IIIA) there was a slight fall in ESBF during the first hour after the glucose feeding from an average fasting level of $1065 \mathrm{cc}$. per min. per $\mathrm{m}^{2}$ to 975 cc. per min. per $\mathrm{m}^{2}$. This represented an 8 per cent fall in flow. During the next thirty minutes of observation there was a tendency toward a return to the control levels, the average ESBF during this period being $1010 \mathrm{cc}$. per min. per $\mathrm{m}^{2}$. A-HV oxygen differences showed a somewhat more striking effect, falling from an average of 4.2 vol. per cent to 3.5 vol. per cent during the first hour of observation, and remaining quite constant at 3.6 vol. per cent during the next $30 \mathrm{~min}$ utes. The splanchnic consumption of oxygen for these three normal subjects fell slightly after glucose feeding from an average fasting level of 38 cc. per min. per $\mathrm{m}^{2}$ to 32 cc. per min. per $\mathrm{m}^{2}$ during the first hour of observation and changed but little during the next 30 minutes averaging 33.5 cc. per min. per $\mathrm{m}^{2}$. Glucose tolerance as measured by peripheral blood levels was at all times within the normal range. The alterations in hepatic blood flow and oxygen consumption were sustained beyond the time at which peripheral blood glucose concentrations (see Table III) had returned to fasting levels.

The effect of glucose feeding upon ESBF and SOC was studied in two cirrhotic subjects. In subject N. P. (Table IIIB) there was a slight initial fall in the ESBF 30 minutes after the glucose feeding from a fasting level of $590 \mathrm{cc}$. per min. per $\mathrm{m}^{2}$ to $540 \mathrm{cc}$. per min. per $\mathrm{m}^{2}$ with return to the control level 50 minutes after ingestion of glucose. There was a slight fall in oxygen consumption 30 minutes after the ingestion of glucose from a 
fasting level of $38 \mathrm{cc}$. per min. per $\mathrm{m}^{2}$ to $32 \mathrm{cc}$. per min. per $\mathrm{m}^{2}$. In subject $\mathrm{P}$. M. (Table IIIB) there was a more striking fall in blood flow in the first 30 minutes after the ingestion of glucose to 765 cc. per min. per $\mathrm{m}^{2}$ from a control level of 1175 cc. per min. per $\mathrm{m}^{2}$. One hour after the insplanchnic oxygen consumption was $24.5 \mathrm{cc}$. per min. per $\mathrm{m}^{2}, 21$ per cent below the control level. Twenty minutes after the ingestion of glucose the splanchnic oxygen consumption was $24.5 \mathrm{cc}$. per min. per $\mathrm{m}^{2}$, having decreased to less than half of control level which was $59 \mathrm{cc}$. per min. per $\mathrm{m}^{2}$. The fall in SOC was noted when the peripheral glucose level was elevated, and 60 minutes after the administration of glucose, when the peripheral blood glucose had returned to the fasting level, the SOC was $48 \mathrm{cc}$. per min. per $\mathrm{m}^{2}, 19$ per cent below the control value.

In the six cirrhotic subjects (Table IIIB) fed glucose $\mathrm{A}-\mathrm{HV}$ oxygen differences fell from an average control level of 4.6 vol. per cent to 4.0 vol. per cent during the first hour of observation and subsequently to 3.4 vol. per cent during the next 30 minutes.

\section{DISCUSSION}

From the present study of the short term effects of protein and glucose feeding in normal and cirrhotic subjects certain conclusions seem warranted. First, after the ingestion of protein there is an increase in estimated splanchnic blood flow, arterio-hepatic vein oxygen difference, and splanchnic consumption of oxygen in both normal and cirrhotic subjects. However, although the changes are qualitatively similar the increases occur somewhat sooner and are of greater magnitude in the normal as compared with the cirrhotic patient. Second, glucose ingestion results in minimal changes in all parameters measured in both normal and cirrhotic subjects. Third, the liver of the fasting, icteric, cirrhotic subject extracts much less oxygen per unit of blood than does the liver of the fasting normal, or of the non-icteric, cirrhotic subject. Following the ingestion of protein by the cirrhotic subject with icterus, the A-HV oxygen difference increases more in absolute values and in percentage changes than it does in the normal, or in the non-icteric cirrhotic subject.
In the fasting state there is little difference in splanchnic oxygen consumption between the cirrhotic and the normal subject despite the lessened blood flow in the former because of the greater oxygen extraction from each unit of blood. During these acute studies following the ingestion of protein, the $\mathrm{A}-\mathrm{HV}$ oxygen difference increases significantly in the normal subject whereas in the cirrhotic subject with approximately the same percentage increase in blood flow, extraction of oxygen per unit of blood increases minimally. This failure of the cirrhotic liver to increase oxygen extraction with increased blood flow may be due to hepato-cellular disease, intrahepatic and extrahepatic shunting of blood, or to perfusion of acellular and non-extracting tissue.

The specific dynamic action of protein has been shown in experimental animals to be due to excess metabolism in the splanchnic region $(7,8)$. This finding has been confirmed in humans by the intravenous administration of amino acids which cause great increases in splanchnic oxygen consumption and little or no change in splanchnic blood flow (9). In the present study the feeding of protein was followed by a significant increase in splanchnic oxygen consumption, similar to that caused by the intravenous administration of amino acids; however, a significant increase was also noted in ESBF. The effect on ESBF of oral amino acids which require no digestion is not known. It would seem unlikely that the increase in ESBF which occurs following the ingestion of protein is related to the increased SOC associated with the metabolism of amino acids. The vascular and metabolic responses of the splanchnic area would appear to depend in part upon the route of administration of a given substance, e.g., the effects of alcohol upon splanchnic blood flow differ with the oral and intravenous routes of administration $(10,11)$. The metabolic processes associated with deamination and the production of urea probably add to the oxygen requirements of the liver. In as short a period as 20 minutes after the ingestion of protein, estimations of the amino acid nitrogen content of blood taken from collateral venous channels in the two patients referred to previously showed a definite rise. The rapidity of the changes noted in SOC after the ingestion of protein in this study may be partly dependent upon the specific dynamic action of amino acids. An 
SDA effect need not necessarily be accompanied by a rise in ESBF (9).

The icteric cirrhotic subjects exhibited very low arterio-hepatic vein oxygen differences in the fasting state and, although these differences increased considerably following the ingestion of protein when measured in percentages or in absolute values, they failed to approach the levels found in either normal or non-icteric cirrhotic subjects. It would appear likely that these observations reflect the severe degree of hepato-cellular dysfunction present in cirrhotic patients with jaundice.

The oral administration of considerable quantities of glucose is not accompanied by significant change in the parameters used in this acute study to demonstrate vascular or metabolic changes in the splanchnic area. Intravenous glucose reduces splanchnic oxygen consumption and blood flow (9). The observed minimal change in splanchnic oxygen consumption may be explained by the conversion of ingested glucose to fat and fatty acids (12) freeing oxygen equivalent to 5 calories per gram of glucose converted. The ingestion of glucose will reduce endogenous protein metabolism in a fasting liver and thus urea production and deamination will diminish (13). It may therefore be possible to achieve a relatively high caloric intake without causing an increase, but perhaps a decrease, in splanchnic oxygen consumption and/ or blood flow. Indeed, our short term data suggest that a fall in splanchnic oxygen consumption may follow the ingestion of glucose. The effects of complex polysaccharides which require digestion have not been studied.

A growing body of evidence has cast suspicion on the role of metabolites of nitrogenous substances in the genesis of hepatic coma (14). Ammonia levels of hepatic vein blood are higher in cirrhotic subjects than in normal individuals after the ingestion of a standard dose of ammonium chloride (15). Small increments in the protein intake of apparently stabilized cirrhotic patients may precipitate hepatic coma (16). These phenomena would appear to be related to the shunting of gastrointestinal venous blood directly into the systemic circulation or to the failure of adequate metabolism by a diseased liver. The present study has demonstrated that the amino acid nitrogen levels of hepatic vein and peripheral blood are higher in cirrhotic patients than in normals after a protein feed. This too is a reflection of the combination of hepato-cellular disease and vascular shunting.

The uniform rise in ESBF following protein feeding may be related to changes in portal vein pressure. Data obtained in our laboratory demonstrate (17) that protein feeding is often followed by a rise in hepatic venule wedge pressure in normals and more so in cirrhotic subjects, whereas glucose feeding does not produce this effect. Hepatic wedge pressure is an excellent reflection of portal vein pressure (18). Since further increases in portal vein pressure in patients with hepatic cirrhosis complicated by portal hypertension are undesirable, this consequence of protein ingestion must be considered in the management of such patients.

To decrease the work of a diseased organ is a basic therapeutic concept. One of the current treatments for hepatic cirrhosis includes the administration of large amounts of protein (19). If increased splanchnic oxygen consumption or work is considered to be deleterious, then it may well be that a high protein intake is unnecessary and perhaps injurious in patients with hepatic cirrhosis. Although no one denies the need for protein repletion in many patients with hepatic cirrhosis and though it is often difficult to correlate the results of acute experimentation with the long term management of a chronic disease, it would now seem, from several points of view, that a nutritious diet with quantities of protein of high biologic value just sufficient to maintain these patients in positive nitrogen balance might be more advantageous than regimens which stress high protein feeding. Glucose causes no increase in splanchnic oxygen consumption or work and so may be a very valuable constituent of the diet of patients with this disease.

\section{CONCLUSIONS}

1. The effects of oral protein and glucose feedings on estimated splanchnic blood flow, splanchnic utilization of oxygen, arterio-hepatic vein oxygen differences have been studied in normal and cirrhotic subjects. These feedings provoke the following responses:

a) In both normal and cirrhotic subjects, protein feeding induced an increase in splanchnic 
blood flow, splanchnic oxygen consumption, and A-HV oxygen differences as compared with their fasting levels. Though the effects are qualitatively the same they are less marked and more delayed in the cirrhotic subject than in the normal individual.

b) In normal and cirrhotic subjects, oral glucose feeding induced little change in splanchnic blood flow, oxygen consumption, and arteriohepatic vein oxygen differences as compared with their control level.

c) There is a small arterio-hepatic vein oxygen difference in the fasting icteric cirrhotic subject, but an increase of this difference occurs following a protein feeding.

2. Amino acid nitrogen levels of peripheral and hepatic vein blood are higher in cirrhotics than in normals after protein feeding.

3. The clinical implications of these observations are discussed.

\section{REFERENCES}

1. Brandt, J. L., Castleman, L., Kelly, J. J., and Greenwald, J., The effect of oral protein feeding upon splanchnic circulation and metabolism. Clin. Res. Proc., 1954, 2, 43.

2. Brandt, J. L., Castleman, L., Greenwald, J., and Kelly, J. J., The effect of oral feedings on splanchnic blood flow and oxygen consumption in normals and in subjects with hepatic cirrhosis. J. Clin. Invest., 1954, 33, 919.

3. Bradley, S. E., Ingelfinger, F. J., Bradley, G. P., and Curry, J. J., The estimation of hepatic blood flow in man. J. Clin. Invest., 1945, 24, 890.

4. Van Slyke, D. D., and Neill, J. M., The determination of gases in blood and other solutions by vacuum extraction and manometric measurement. $I$. J. Biol. Chem., 1924, 61, 523.

5. Nelson, N., A photometric adaptation of the Somogyi method for the determination of glucose. J. Biol. Chem., 1944, 153, 375.

6. Sahyum, M., The determination of amino acid nitrogen in blood and urine; a rapid colorimetric method. J. Lab. \& Clin. Med., 1939, 24, 548.
7. Dock, W., The relative increase in metabolism of the liver and of other tissues during protein metabolism in the rat. Am. J. Physiol., 1931, 97, 117.

8. Mann, F. C., The effects of complete and of partial removal of the liver. Medicine, 1927, 6, 419.

9. Myers, J. D., The effects of the intravenous administration of glucose and amino acids on the hepatic blood flow and splanchnic oxygen consumption of man. Federation Proc., 1948, 7, 83.

10. Mendeloff, A. I., Effect of intravenous infusions of ethanol upon estimated hepatic blood flow in man. J. Clin. Invest., 1954, 33, 1298

11. Smythe, C. McC., Heinemann, H. O., and Bradley, S. E., Estimated hepatic blood flow in the dog. Effect of ethyl alcohol on it, renal blood flow, cardiac output and arterial pressure. Am. J. Physiol., 1953, $172,737$.

12. Stetten, DeW., Jr., and Boxer, G. E., Studies in carbohydrate metabolism; I. The rate of turnover of liver and carcass glycogen, studied with the aid of deuterium. J. Biol. Chem., 1944, 155, 231.

13. Cathcart, E. P., The Physiology of Protein Metabolism. New ed., London, Longmans, 1921.

14. Phillips, G. B., Schwartz, R., Gabuzda, G. J., Jr., and Davidson, C. S., The syndrome of impending hepatic coma in patients with cirrhosis of the liver given certain nitrogenous substances. New England J. Med., 1952, 247, 239.

15. White, L. P., Phear, E. A., Summerskill, W. H. J., and Sherlock, S., Ammonium tolerance in liver disease: observations based on catheterization of the hepatic veins. J. Clin. Invest., 1955, 34, 158.

16. Schwartz, R., Phillips, G. B., Seegmiller, J. E., Gabuzda, G. J., Jr., and Davidson, C. S., Dietary protein in the genesis of hepatic coma. New England J. Med., 1954, 251, 685.

17. Castleman, L., Brandt, J. L., Ruskin, H. D., and Greenwald, J., The effect of alimentation on wedged hepatic vein pressure. To be published.

18. Reynolds, T. B., Balfour, D. C., Jr., Levinson, D. C., Mikkelson, W. P., and Pattison, A. C., Comparison of wedged hepatic vein pressure with portal vein pressure in human subjects with cirrhosis. J. Clin. Invest., 1955, 34, 213.

19. Patek, A. J., Jr., Post, J., Ratnoff, O. D., Mankin, H., and Hillman, R. W., Dietary treatment of cirrhosis of the liver: results in one hundred and twentyfour patients observed during a ten year period. J. A. M. A., 1948, 138, 543. 